\title{
IMPROVED FLOWSHEET OF WASTEWATER TREATMENT FROM NITROGEN-CONTAINING COMPOUNDS
}

\author{
O. SEMENOVA ${ }^{1}$, L. RESHETNIAK ${ }^{2}$, N. BUBLIENKO ${ }^{1}$, O. SALAVOR ${ }^{1}$, \\ E. SMIRNOVA ${ }^{1}$ \\ ${ }^{1}$ Natioanal University of Food Technology, Kyiv \\ ${ }^{2}$ National Aviation University, Kyiv
}

\begin{abstract}
Wastewater containing nitrogen compounds stimulates the development of plankton, algae, and disrupts oxygen regime, which negatively affect the livelihoods of aquatic organisms. Sewage treatment from nitrogen compounds is carried out by active suspended sludge or immobilized active biomass.
\end{abstract}

Keywords: wastewater, nitrification, denitrification, biological treatment, aerotank-clarifier.

Untreated and undertreated sewage is a major reason for pollution of water bodies. A number of reservoirs in Ukraine exceed fixed norms for ammonia nitrogen - by $2-15$ times, nitrates - by $7-20$ times.

The presence of nitrogen in wastewater leads to a massive development of plankton, algae, promotes specific taste, and odor of water, causes change of oxygen conditions and norms of aquatic organisms livelihood, creates additional difficulties during its treatment. The presence of nitrogen in the reverse water leads to fouling of pipelines and process equipment. Such organic and mineral nitrogen compounds as proteins, amino acids, amines, pyrimidines, purines, ammonium, nitrites, nitrates, etc. are present in lots of wastewater in different sectors of food industry [1].

Nitrification is the process of ammonium nitrogen oxidation by atmospheric oxygen up to nitrites and nitrates. This process is carried out by nitrifying bacterial genera Nitrosomonas, Nitrosococcus, Nitrospiraceae. 


$$
\begin{aligned}
2 \mathrm{NH}_{4}^{+}+3 \mathrm{O}_{2} & \longrightarrow 2 \mathrm{NO}_{2}^{-}+2 \mathrm{H}_{2} \mathrm{O}+4 \mathrm{H}^{+} \\
2 \mathrm{NO}_{2}{ }^{-}+\mathrm{O}_{2} & \longrightarrow 2 \mathrm{NO}_{3}^{-}
\end{aligned}
$$

Under denitrification, the process of renewal of convertion and nitrates in to free nitrogen, takes place:

$$
\mathrm{NO}_{3}^{-} \longrightarrow \mathrm{NO}_{2} \longrightarrow \mathrm{NO} \longrightarrow \mathrm{N}_{2} \mathrm{O} \longrightarrow \mathrm{N}_{2}
$$

Denitrification helps wastewater treatment both from organic compounds and nitrogen compounds $\left(\mathrm{NO}_{2}{ }^{-}\right.$and $\left.\mathrm{NO}_{3}{ }^{-}\right)$. Carbohydrates, alcohols, organic acids, etc can be organic sewage substrate of food enterprises, in denitrification process [2].

The process of nitrification is the final stage of mineralization of nitrogencontaining organic contaminants. The presence of nitrates in the purified wastewater is one of the indicators of the degree of their full purification, so it is necessary to use such treatment facilities, that provided all optimal conditions for the life of nitrifying bacteria.

Organic and mineral nitrogen compounds (proteins, amino acids, amines, purines pyrimidines, ammonia, nitrites, nitrates, etc.). present in wastewater of many industries: petrochemical, medical, microbiological, food, agrochemical and household waters [3].

For wastewater treatment from the biological elements (nitrogen and phosphorus) the physical, chemical, biological, and combined methods are used.

Waste water from mentioned industries is purified from organic substances by conventional biological methods (in aeration tank), but the nitrogen compounds in them almost not removed. To remove these compounds it is needed biological methods with the use of suspended culture of activated sludge or attached sludge microorganisms, or combination of these two methods.

For processes of nitrification and denitrification can be used aerotanks and biofilters.

The overall burden on the biological structures by nitrogen (sum of $\mathrm{NH}_{4}^{+}$and $\mathrm{N}_{\text {org.) }}$ in 3-4 times exceeds maximum allowed for given structures, calculated for ammonia nitrogen. Therefore, the final concentration of $\mathrm{N}_{\text {org. }}$ (in some samples of 
ammonia nitrogen) in the purified waste waters of food enterprises is quite high. For the process of nitrification optimum $\mathrm{pH}$ is $7-9$.

Table 1

Concentration of different forms of nitrogen in industrial waste waters

\begin{tabular}{|c|c|c|c|c|}
\hline Waste water from food & \multicolumn{4}{|c|}{ Concentration, $\mathrm{N}, \mathrm{mg} / \mathrm{dm}^{3}$} \\
\cline { 2 - 5 } enterprises & $\mathrm{N}_{\text {org. }}$ & $\mathrm{NH}_{4}^{+}$ & $\mathrm{NO}_{2}^{-}$ & $\mathrm{NO}_{3}{ }^{-}$ \\
\hline $\begin{array}{c}\text { Before feeding to } \\
\text { treatment plants }\end{array}$ & 35,0 & 26,3 & 0,1 & 0,4 \\
\hline Purified & 7,5 & 1,9 & 1,0 & 10,5 \\
\hline
\end{tabular}

From the $\mathrm{pH}$ value depends the availability of inorganic carbon for the nitrifying bacteria. By reducing $\mathrm{pH}$ the reaction equilibrium states of carbon shifts to the left and most of the carbon is in the form of carbonic acid. Increasing of $\mathrm{pH}$ is also have negative impact on the process of nitrification. Thus in the environment there is free ammonia, which is a nitrification inhibitor.

Nitrifying organisms require the creation of definite redox potential of the environment: bigger it is, the more lower should be the optimal $\mathrm{pH}$ for nitrificators. In biological wastewater treatment process for the implementation of nitrification it is required the alkalinity in the range of $2 \mathrm{mg}$-eq. $\mathrm{HCO}_{3}$ in $1 \mathrm{mg}$-eq. ammonium nitrogen. Denitrifying bacteria have the ability to recover nitrate via nitrite to gaseous nitrous oxide and nitrogen. Unlike nitrification, denitrification increases the alkalinity of the environment and causes an increase in $\mathrm{pH}$.

The sequence of individual process steps and purification schemes can be different. Most often such is found: denitrification, oxidation of organic compounds, nitrification, oxidation of organic compounds, nitrification, denitrification.

Wastewater treatment from nitrogen compounds by chlorination, ozonation, ultraviolet irradiation, electrolysis, demineralization requires expensive reagents and equipment.

The purpose of this research work was to study an oxidation of pollutions of nitrogenous containing wastewaters in typical aerotanks. However, this process is difficult to achieve because nitrogen compounds are not completely removed from wastewaters. 
For nitrogen removal combined and separate treatment systems may be used. In combined treatment systems processes of nitrification and denitrification are supposed to be carried out within one building, and separate, suggest - separate nitrification and denitrification [4].

The sequence of certain stages of sewage treatment process can be different. For example, for the removal of contaminated wastewater, one can use the following scheme:

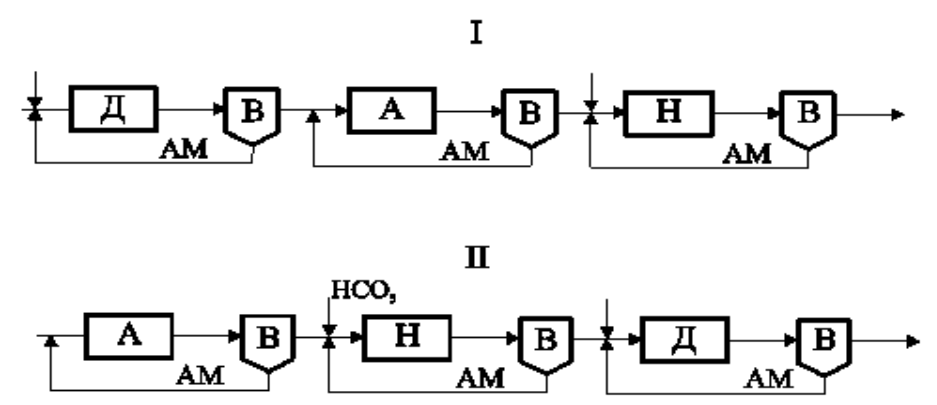

Fig. 1. Schemes of nitrogen removal with different denitrification zone position: I - at the beginning of the process; II - at the end of the process; where $\mathrm{D}$ - denitrificator, $\mathrm{B}$ - tank, A - aerotank, $\mathrm{H}$ - nitrificator

Experiments were conducted in the aeration tank-clarifier, whose scheme is presented in Figure 2.

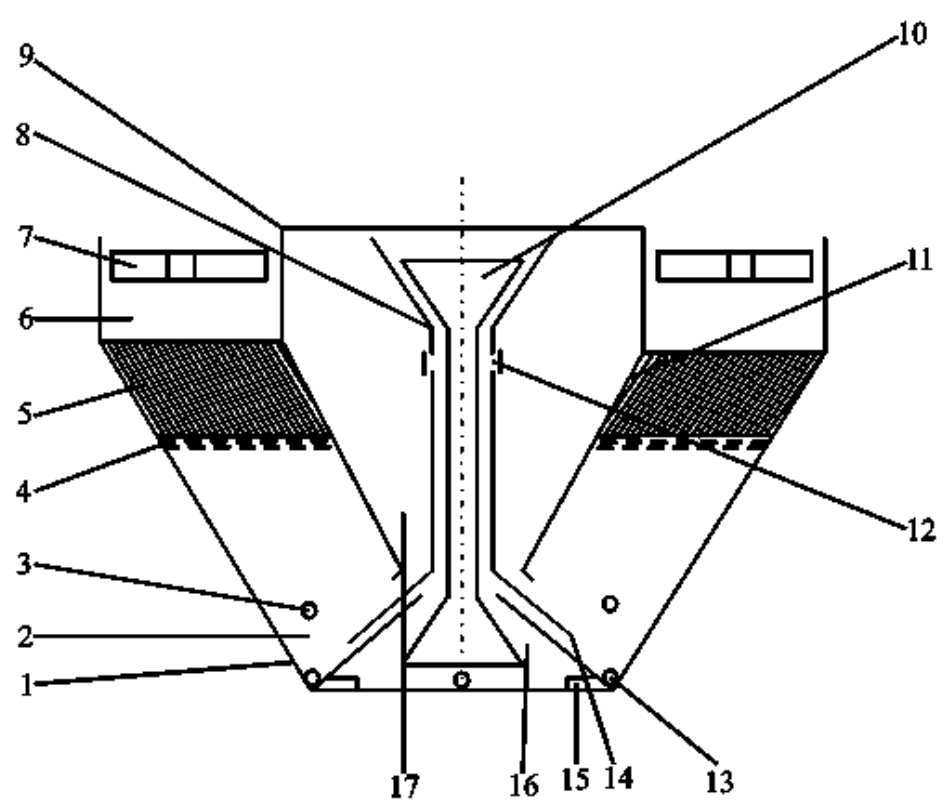

Fig. 2. Laboratory scheme of aeration tank-clarifier: 1 - body; 2 - clarification zone; 3 - circulating active sludge emission; 4 - net-shaped electrode; 5 - laminorizators; 6 - protective zone; 7 - drainage trays; 8 - partition; 
9 - overlap; 10 - partition; 11 - overflow gate windows; 12 - emission system; 13 - "tooth"; 14 - aerators; 15 - aeration zone; 16 - degassing zone

Indicators of ammonium nitrogen, nitrates, nitrites and active sludge age were determined by standard methods.

A number of nitrogen compounds in urban wastewater is about $30-60 \mathrm{mg} / \mathrm{dm}^{3}$, in some industrial wastewater $-1000 \mathrm{mg} / \mathrm{dm}^{3}$ [5].

To solve the problem of nitrogen-containing wastewater treatment aerotankclarifiers should be used which create anaerobic zones where denitrification will occur, due to removal of nitrogen compounds that is usually carried out in practice under anaerobic conditions.

However, experiments carried out at the VODHEO Institute by A. A. Bondarev, N.V. Zahvotova and others, made possible to carry out denitrification under aerobic conditions without additional organic substrate. The efficiency of denitrification increases with increasing a redox potential [6].

The ability of active sludge to denitrification under aerobic conditions, with the appropriate $\mathrm{rH}_{2}$ environment is the reason for the possibility to carry out nitro- and denitrification process simultaneously in a single-aerated system.

Analysis of various biological systems and factors influencing the effectiveness of nitro-, denitrification processes, allowed to determine the type of reactors operating on the principle of flowsheet settings with suspended layers of microorganisms in active sludge [7].

Such a type of reactors to a greater extent meets the requirements favorable to the simultaneous activity of heterotrophic, nitrifying (autotrophic) and denitrifying (facultative anaerobes) microorganisms.

Experiments on the laboratory installation, the aeration tank-clarifier were made under temporary aeration from 2 to 8 hours, the consumption of wastewater varied from $1 \mathrm{~m}^{3} / \mathrm{h}$ to $2 \mathrm{~m}^{3} / \mathrm{h}$. 
The concentration of active sludge was determined depending on the value of the sludge age and varied within the range from 2 to $8 \mathrm{~g} / \mathrm{dm}^{3}$, the sludge age ranged from 44 to 48 days.

The aerotank-clarifier comprises a body divided by partitions into aeration chambers, degassing and clarifying and drainage travs with corrugated hoses. Wastewater enters the aeration cliamber where the air is supplied through porous aerators, which are made of ceramic filtroses, passes through aeration zone and passes out of buildings from a pipe. Since the zone of aeration is sealed, aeration pressure is under head. Flows of air bubbles moving upwardly through the "tooth", promote the environment suction through slots between the "tooth" and partition. This suction moves the sludge from the clarification zone to the zone of aeration. The top of partitions have overflow windows through which the mixture controlled by backwater from the side of the aeration zone is poured into the degassing zone in which the flow is slowing and air bubbles are separating. From the drainage zone a silt mixture enters the clarification chamber. Since at the top of the degassing zone near the overflow windows the dynamic pressure increases by backwater from the side of the aeration zone, while at the bottom of the clarification zone the dynamic pressure decreases, a stable intense recirculation flow which provides silt mixture transporting from the aeration zone to the zone of clarification as well as recirculation sludae, from the clarification zone of silt mixture in a suspended layer backward to the zone of aeration. Thus, active sludge in degassing zones and suspended layers as well as circulation of active sludge after silt mixture in a suspended layer have been supplied with nutrients and dissolved oxygen to go on working in the aeration zone . The total working volume, occupied by active sludge, is the volume of the aeration, degassing zones and a suspended layer is called the reaction volume. This volume performs oxidation of sewage pollution. Flakes of active sludge precipitate as their hydraulic particle size at a certain flow level is greater than the vertical component of the flow. Precipitate of particles to the bottom is by the high speed at the bottom of recirculating flow, that's why a pseudorarefied suspended layer of active shedge is 
produced. This layer is characterized by a vortex structure, homogeneity as for its total mass, and serves as a filter, passing through which a silt mixture is clarified [8].

At the beginning of the process of treatment the influence of oxygen concentration in the clarification zone a the effect of denitrification has been determined. This was done to determine the needed mode of recycling.

According to known theories, decrease of dissolved oxygen in sludge mixture is considered to affect the increase of denitrification.

To reduce concentration of dissolved oxygen in the clarification zone recirculation decreased within it and the aeration zone.

Under all treatment inverstigations a deep removal of pollution was obtained the value of the main parameters ranged: COD - 42-52 $\mathrm{mg} \mathrm{O} \mathrm{O}_{2} / \mathrm{dm}^{3}$, $\mathrm{BSK}_{5}-1.6-4 \mathrm{mg} / \mathrm{dm}^{3}$, suspended matter - $7.5-11 \mathrm{mg} / \mathrm{dm}^{3}$, $\mathrm{NH}_{4}{ }^{+}-0.32-2.40 \mathrm{mg} / \mathrm{dm}^{3}, \mathrm{NO}_{2}{ }^{-}-0.040-0.25 \mathrm{mg} / \mathrm{dm}^{3}, \mathrm{NO}_{3}{ }^{-}-0.28-7.2 \mathrm{mg} / \mathrm{dm}^{3}$.

The research results show that with increasing the age of sludge a final amount of ammonium nitrogen in treated water decreases. The concentration of nitrate nitrogen for all values of the sludge age corresponds to an intense process of denitrification [9].

The value of the redox potential of the silt mixtures $\mathrm{rN}_{2}=19.0$ - was in a favorable for nitrification range, due to it the concentration of nitrite, although having low values, was still not as high as the maximum permissible concentration (MPC).

Aerobic nitrification and denitrification of wastewater technology in the aeration tank-clarifiers has allowed to reduce by 2.5 times the treatment process, by 10 times to decrease the need for aerege, to eliminate sludge recirculation of pumping stations, equipment for mixing in denitryficators, secondary clarifiers.

Under all investigated modes a deep removal of pollution took place- the value of basic indicators ranged: $\mathrm{COD}-52 \mathrm{mg} \mathrm{O} \mathrm{O}_{2} / \mathrm{dm}^{3}$, BSK5 - $4 \mathrm{mg} \mathrm{O} / \mathrm{dm}^{3}$, suspended matter $-10 \mathrm{mg} / \mathrm{dm}^{3}, \mathrm{NH}_{4}{ }^{+}-0.35-2.24 \mathrm{mg} \mathrm{N} / \mathrm{dm}^{3}, \mathrm{NO}_{2}^{-}-0.039-0.23 \mathrm{mg} \mathrm{N} / \mathrm{dm}^{3}$, $\mathrm{NO}_{3}-0.22-6.6 \mathrm{mg} \mathrm{N} / \mathrm{dm}^{3}$.

The results of experiments confirm that with the increasing of the active sludge age from 32 days to 48 days ammonium nitrogen content decreases. 
The concentration of nitrate nitrogen for all values of sludge age corresponds to the MCL, indicating the intense process of denitrification. The concentration of nitrite although had low values, but did not achieve the MAC [10].

\section{CONCLUSIONS}

Based on the investigations of purification of nitrogen-containing waste water, we can make the conclusion that this process is best done in the aerotank-clarifier because this type of reactor best meets the requirements which favorable to the simultaneous activity of activated sludge organisms. Also, results of researches show that age of the sludge influences on wastewater purification process, i.e. with increasing of sludge age the amount of ammonia nitrogen decreases, indicating of the intensification of the process of denitrification.

\section{REFERENCES}

1. Левандовський Л.В., Природоохоронні технології та обладнання: підруч. / Л. В. Левандовський, Н.О. Бублієнко, О.І. Семенова - К.: НУХТ, 2013. $-243 \mathrm{c}$.

2. Запольський А.К. Водопостачання, водовідведення та якість води: навч. посіб. / А.К. Запольський. - К.: Вища школа. - 2005. - 671 с.

3. Wastewater treatment. Biological and chemical processes / [Henze M., Harremoes P., La Cour et al.] - Moscow: World. - 2009. - 77 c.

4. Martin G.S. Cell signaling and cancer / G. S. Martin // Cancer Cell. - 2003. Vol. 4. - P. 167-174.

5. Дика О.П. Біоплівка та іï значення в процесі очищення стічних вод / О.П. Дика, В.С. Тотміна // Наука та інновація: X міжнародна науковопрактична конференція, 2014 р. - K.: Nauka i studia, 2013. - C. 29-31.

6. Brandhorst K. Efficient computation of compliance matrices in redundant internal coordinates from Cartesian Hessians for nonstationary points / K. Brandhorst, J. Grunenberg // J. Chem. Phys. - 2010. - Vol. 132. - P. 184101184107. 
7. European Organic Farming Statistics. Compiled by the Research Institute of Organic Agriculture FiBL, 2009.

8. Нікітін Г.О. Екологія харчових виробництв: конспект лекцій для студентів спец 7.070801 «Екологія та охорона навколишнього середовища» ден. форми навч. / Г.О. Нікітін - К.: УДУХТ, 2000. - 56 с.

9. Adsorption of zinc and copper ions on natural and ethylenediamine modified montmorillonite / [O. Kozak et al.] // Ceramics - Silikaty. - 2010 - Vol. 54, Is. № 1. - P. 78-84.

10. Cancer as an evolutionary and ecological process / [Merlo L.M.,
[Me Pepper J.W., Reid B.J., Maley C.C.] // Nat. Rev. Cancer. - 2006. - Vol. 12. P. 924-935.

\title{
УДОСКОНАЛЕНА ТЕХНОЛОГІЧНА СХЕМА ОЧИЩЕННЯ СТІЧНИХ ВОД ВІД АЗОТОВМІСНИХ СПОЛУК
}

\author{
O.І. СЕМЕНОВА ${ }^{1}$, Л.Р. РЕШЕТНЯК ${ }^{2}$, Н.І. БУБЛІСНКО ${ }^{l}$, О.М. САЛАВОР ${ }^{l}$, \\ C.C. CMIPHOBA ${ }^{1}$ \\ ${ }^{1}$ Національний університет харчових технологій, м. Київ \\ ${ }^{2}$ Національний авіаційний університет, м. Київ
}

Стічні води, які містять сполуки азоту стимулюють розвиток планктону, водоростей та порущують кисневий режим, що негативно впливає на життедіяльність гідробіонтів. Очищення стічних вод від сполук азоту здійснюється активним мулом у завислому стані або з використанням іммобілізованої активної біомаси.

Ключові слова: стічна вода, нітрифікачія, денітрифікація, біологічне очищення, аеротенк-прояснювач. 


\title{
УСОВЕРШЕНСТВОВАННАЯ ТЕХНОЛОГИЧЕСКАЯ СХЕМА ОЧИСТКИ СТОЧНЫХ ВОД ОТ АЗОТСОДЕРЖАЩИХ СОЕДИНЕНИЙ
}

\author{
О.И. СЕМЕНОВА ${ }^{1}$, Л.Р. РЕШЕТНЯК ${ }^{2}$, Н.И. БУБЛИЕНКО \\ О.М. САЛАВОР ${ }^{l}$, Е.С. СМИРНОВА \\ ${ }^{1}$ Национальный университет пищевых технологий, г. Киев \\ ${ }^{2}$ Национальный авиационный университет, г. Киев
}

Сточные воды, содержащие соединения азота стимулируют развитие планктона, водорослей и нарушают кислородный режим, что отрицательно влияет на жизнедеятельность гидробионтов. Очистка сточных вод от соединений азота осуществляется активным илом во взвешенном состоянии или с использованием иммобилизованной активной биомассь.

Ключевые слова: сточная вода, нитрификачия, денитрификачия, биологическая очистка, аэротенк-осветлитель. 